Jurnal Laut Khatulistiwa, Vol. 4 No. 3 (October, 2021), Hal. 119-129.

\title{
Kondisi Komunitas Terumbu Karang di Teluk Palembang Pulau Lemukutan Kalimantan Barat
}

\section{Condition of Coral Reef Community in Palembang Bay Lemukutan Island West Kalimantan}

\author{
M. Abdul Rasyid Rusli ${ }^{*}$, Nora Idiawati2 ${ }^{2}$ Yusuf Arief Nurrahman² \\ ${ }_{1}^{1}$ Program Studi Ilmu Kelautan, Fakultas Matematika dan Ilmu Pengetahuan Alam, Pontianak, Indonesia \\ ${ }^{2}$ Laboratoorium Ilmu Kelautan, Fakultas Matematika dan Ilmu Pengetahuan Alam, Pontianak, Indonesia \\ *E-mail : ruslyabdul@gmail.com
}

Received : 21 May 2021; Accepted: 8 October 2021

Published: 31 October (C) Author(s) 2021. This article is open access

\begin{abstract}
Ecologically, the coral reef community has a function as a place for the development of marine life, a place for food for marine life, a barrier to abrasion, and to stabilize the shoreline from the erosion of the waves. The purpose of this study was to determine the condition of the coral reef community and the condition of environmental parameters in Palembang Bay, Lemukutan Island, West Kalimantan. This study used themethod underwater photo transect with alength of line transect 50 meters at 2 depths of 3-4 $\mathrm{m}$ and 6-7 $\mathrm{m}$, observations were made at 3 different stations which represent the Palembang Bay area, Lemukutan Island, West Kalimantan. The results showed that the percentage of live coral cover at a value of $44.25 \%$ can be categorized as moderate. The dominant type is Acropora sp. (ACSP.) 31.73\%. Water quality parameters in Palembang Bay are not good because the values of salinity, brightness and currents have not yet met the optimal values for coral reef growth.
\end{abstract}

Keywords : Community conditions, coral reefs, Underwater photo tansect, and Palembang Bay

\begin{abstract}
Abstrak
Secara ekologis komunitas terumbu karang memiliki fungsi sebagai tempat perkembangan biota laut, tempat mencari makan bagi biota laut, penahan abrasi, serta menstabilkan garis pantai dari kikisan ombak. Tujuan dari penelitian ini adalah mengetahui kondisi komunitas terumbu karang dan kondisi parameter lingkungan di Teluk Palembang, Pulau Lemukutan Kalimantan Barat. Penelitian ini menggunakan metode underwater photo transect dengan panjang line transect 50 meter pada 2 kedalaman 3-4 m dan 6-7 m, pengamatan dilakukan pada 3 stasiun yang berbeda yang dimana mewakili kawasan Teluk Palembang, Pulau Lemukutan, Kalimantan Barat. Hasil penelitian didapat persentase tutupan karang hidup berada pada nilai 44,25\% dapat dikategorikan sedang. Jenis yang mendominasi yaitu Acropora sp. (ACSP.) 31,73\%. Parameter kualitas perairan di Teluk Palembang termasuk kurang baik karena nilai dari salinitas, kecerahan dan arus belum memenuhi nilai optimal untuk pertumbuhan terumbu karang.
\end{abstract}

Kata kunci : Kondisi komunitas, Terumbu karang, Underwater photo tansect, dan Teluk Palembang

\section{Pendahuluan}

Pulau Lemukutan memiliki luas sekitar 1.236 ha yang termasuk pulau terbesar dari gugusan Pulau Kabung, Penata Besar, Penata Kecil dan Pulau Randayan. Pulau Lemukutan dapat dicapai melalui akses jalan laut. Terdapat dua dermaga tempat bersandar motor air tujuan Pulau Lemukutan, dermaga yang pertama terletak di Teluk Suak dan yang kedua adalah Dermaga Samudra Indah (Ruliyansyah, 2016). Masyarakat Pulau Lemukutan sebagian besar berprofesi sebagai nelayan dan beberapa lainnya menjadi pelaku pariwisata, seperti menyewakan penginapan, alat snorkeling, serta menyediakan jasa sebagai tourguide. masyarakat lokal sangat menggantungkan hidup dari komunitas 
Jurnal Laut Khatulistiwa, Vol. 4. No. 3 (October, 2020), Hal. 119-129.

terumbu karang. Wilayah ekosistem terumbu karang aktif dimanfaatkan masyarakat Pulau Lemukutan (Pranata, 2018).

Terumbu karang mempunyai peran utama sebagai habitat (tempat tinggal), tempat mencari makan (feeding ground), tempat asuhan dan pembesaran (nursery ground) dan tempat pemijahan (spawning ground) bagi berbagai biota yang hidup disekitar dan atau berasosiasi dengan terumbu karang (Bengen, 2009). Secara ekologi terumbu karang memiliki fungsi sebagai tempat perkembangan biota laut, tempat mencari makan bagi biota laut, penahan abrasi, serta menstabilkan garis pantai dari kikisan ombak. Dari segi ekonomi, terumbu karang merupakan ekosistem yang sering dimanfaatkan sebagai tempat wisata karena keindahannya serta tempat mencari ikan bagi nelayan karena kekayaan biodiversity didalamnya (Damanhuri, 2003).

Aktivitas pariwisata, Perubahan lingkungan, kegiatan perikanan yang tidak ramah lingkungan serta kurangnya penelitian mengenai kondisi komunitas terumbu karang di Pulau Lemukutan, bisa mempengaruhi kondisi komunitas terumbu karang dan pada akhirnya bisa berdampak pada masyarakat di Pulau Lemukutan karena berkurangnya komunitas terumbu karang. Pentingnya peran terumbu karang untuk kehidupan, maka perlunya dilakukan penelitian mengenai kondisi komunitas terumbu karang di Teluk Palembang Pulau Lemukutan, Kalimantan Barat.

Penelitian ini dilakukan untuk mengetahui kondisi terumbu karang di Teluk Palembang, Pulau Lemukutan, Kalimantan Barat dan untuk mengetahui kondisi parameter lingkungan di Teluk Palembang, Pulau Lemukutan Kalimantan Barat. Tujuan dari penelitian ini adalah Untuk mengetahui kondisi komunitas terumbu karang dan kondisi parameter lingkungan di Teluk Palembang, Pulau Lemukutan Kalimantan Barat

\section{Metodologi Penelitian}

\subsection{Waktu dan Tempat Penelitian}

Penelitian ini dilaksanakan pada bulan Agustus 2020 di Teluk Palembang, Pulau Lemukutan, Kalimantan Barat (Gambar 1). Penelitian ini dilakukan pada tiga stasiun pengamatan. Penentuan titik lokasi dilakukan dengan metode survey dengan penentuan stasiun pengamatan secara purposive sampling. Menurut Notoatmodjo (2002) metode purposive sampling merupakan penentuan lokasi dengan beberapa pertimbangan tertentu oleh pengamat, berdasarkan ciri atau sifat-sifat populasi yang sudah diketahui sebelumnya. Lokasi pengamatan terbagi menjadi 3 titik stasiun pengamatan yaitu Stasiun 1, Stasiun 2, dan Stasiun 3 dengan 2 kedalaman berbeda pada setiap stasiunnya yaitu dikedalaman 3-4 dan 67 meter sejajar garis pantai. Setiap lokasi mewakili kawasan Teluk Palembang, Pulau Lemukutan, Kalimantan Barat.

Pengambilan data parameter lingkungan seperti suhu, salinitas, DO, $\mathrm{pH}$, arus dan kecerahan yang merupakan parameter kualitas air bertujuan untuk memperoleh data sekunder yang mendukung hasil dari pendataan komunitas terumbu karang

Pengambilan data terumbu karang dilakukan di zona neritik pada 3 stasiun pengamatan dengan panjang line transek 50 meter pada kedalaman 3-4 dan 6-7 meter sejajar garis pantai. Titik awal yang ditandai dengan patok besi dan pelampung sebagai penanda titik meter ke-0. Dilakukan pengambilan data dengan melalukan pemotretan bawah air dimana sudut pengambilan foto tegak lurus terhadap dasar substrat. Luas area minimal bidang pemotretan adalah $2552 \mathrm{~cm}^{2}$ atau (58 x 44) $\mathrm{cm}^{2}$. Pemotretan dilakukan pada jarak $60 \mathrm{~cm}$ dari dasar substrat (Giyanto et al., 2010). Selanjutnya setelah semua pengambilan foto selesai kemudian foto di analisis.

Pengambilan data foto dengan cara pemotretan dilapangan dilakukan oleh 2 orang penyelam yang memiliki peran yang berbeda sebagai fotografer dan yang memegang frame serta nomor untuk memudahkan saat mengiden. Pemotretan dilakukan menggunakan kamera Canon G1X. Foto-foto hasil pemotretan bawah air di sepanjang interval $1 \mathrm{~m}$ garis transek tersebut selanjutnya dianalisis untuk mendapatkan data-data yang kuantitatif seperti persentase tutupan masingmasing biota atau substrat.

Penentuan titik acak digunakan dengan menentukan banyaknya titik acak (random point) yang dipakai untuk menganalisis foto. Jumlah titik acak yang digunakan adalah sebanyak 30 buah untuk setiap framenya, dan 


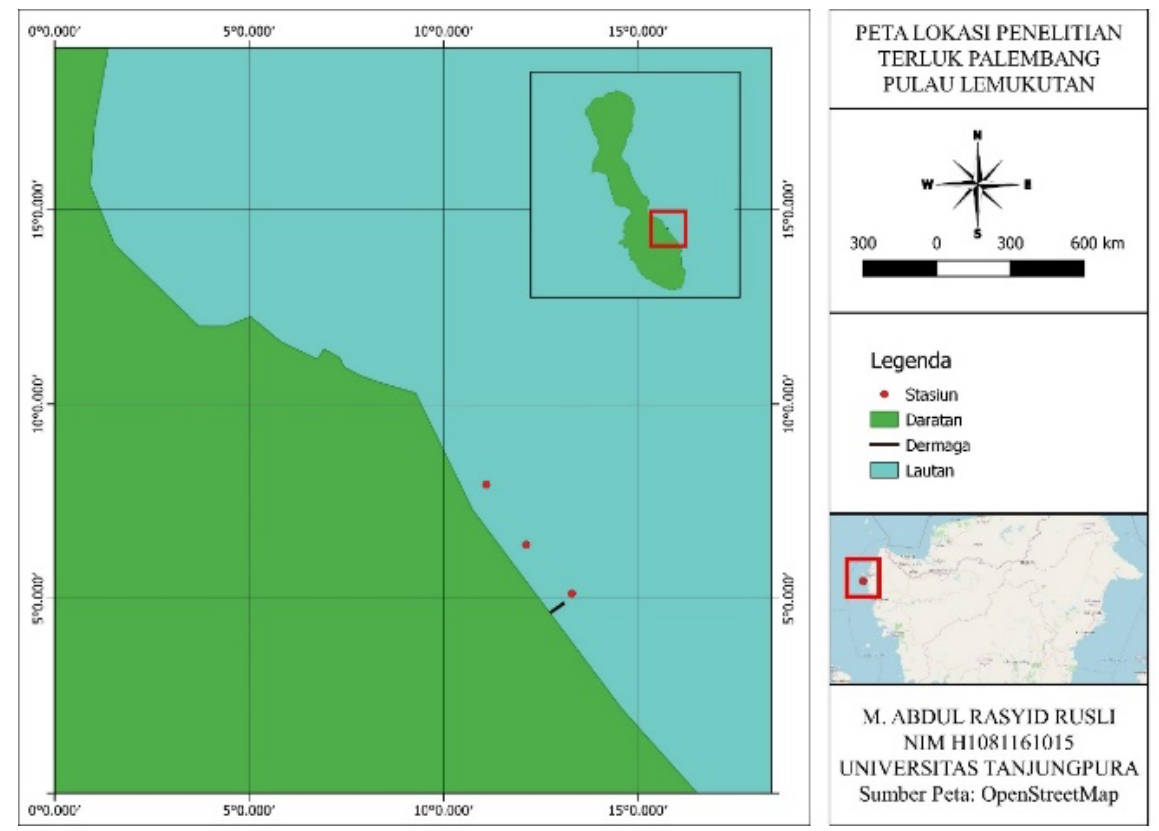

Gambar 1. Peta lokasi penelitian

ini sudah representatif untuk menduga persentase tutupan kategori dan substrat (Giyanto et al., 2010). cara ini merupakan aplikasi dari penarikan sampel, dimana sebagai populasinya adalah semua biota dan substrat yang terdapat dalam frame foto, sedangkan sampelnya adalah titik-titik yang dipilih secara acak pada foto tersebut. Dengan cara ini, data yang dicatat hanyalah biota dan substrat yang berada tepat pada posisi titik yang telah ditentukan secara acak oleh software CPCe.

Berdasarkan proses analisis foto yang dilakukan terhadap setiap frame foto yang dilakukan, maka dapat diperoleh nilai persentase tutupan kategori untuk setiap frame dihitung berdasarkan rumus sebagai berikut :

$\mathrm{P}=\frac{\text { jumlah titik kategori }}{\text { banyaknya titik acak }} \times 100 \%$
Dengan $\mathrm{P}$ merupakan Persentase tutupan kategori.

Klasifikasi kondisi terumbu karang berdasarkan persentase penutupannya, menurut KepMen LH No 4 tahun 2001, dapat dilihat pada Tabel 1.

\section{Hasil dan Pembahasan}

\subsection{Kondisi Daerah Penelitian \\ 3.1.1. Tutupan Karang}

Berdasarkan Keputusan Menteri Lingkungan Hidup Nomor 4 Tahun 2001, kondisi terumbu karang ditentukan dari persentase tutupan karang hidup (HC), karena komponen utama dalam ekosistem terumbu karang adalah karang kerasnya (Giyanto, 2017) dan juga menurut Sukarno (1993) Status kondisi terumbu karang ditentukan menggunakan tingkat tutupan karang hidup.

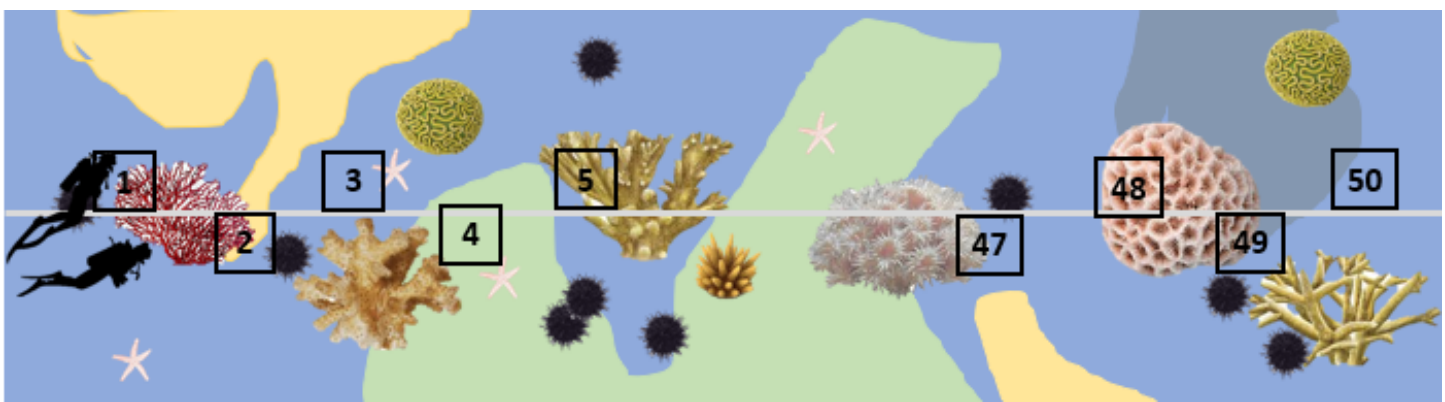

Gambar 2. llustrasi dalam penarikan sampel dengan metode Transek Foto Bawah Air (UPT) 
Jurnal Laut Khatulistiwa, Vol. 4. No. 3 (October, 2020), Hal. 119-129.

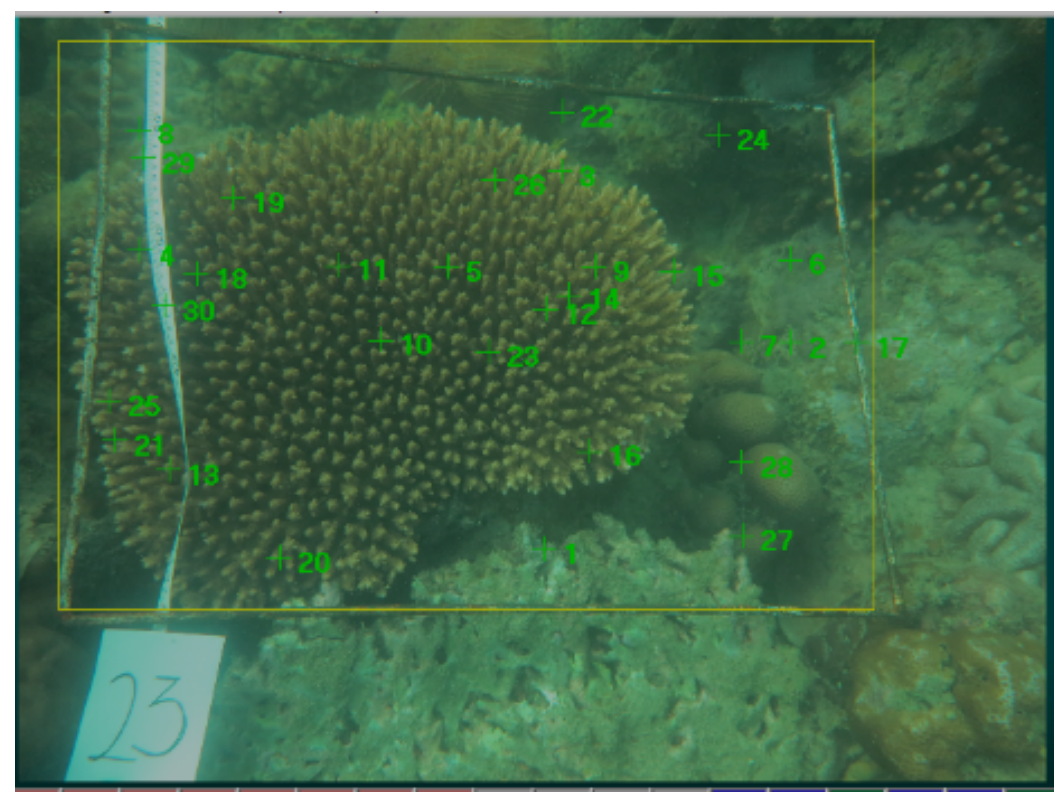

Gambar 3. Random point

Tutupan karang HC pada Stasiun 1 pada kedalaman 3-4 $\mathrm{m}$ sebesar $36,71 \% \%$ sedangkan nilai HC pada kedalaman 6-7 m yaitu 47,89\%. tingginya persentase dari tutupan DCA disebabkan karena lokasi Stasiun 1 merupakan lokasi dekat dermaga yang dimana perairan aktif digunakan sebagai tempat singgah kapal, jangkar dari kapal merupakan salah satu penyebab terjadinya patahan atau kerusakan terumbu karang. Pada kedalaman 6-7 m juga nilai DCA cukup tinggi yaitu 43,42\%, dibandingkan dengan kedalaman 3-4 m nilai DCA pada kedalaman 3$4 \mathrm{~m}$ jauh lebih tinggi dikarenakan lokasi tempat singgah kapal.

Penyebab kondisi terumbu karang yang tingginya tutupan karang mati beralga (DCA) dimana tutupan DCA merupakan tutupan yang mendominasi, pada kedalaman 3-4 m yaitu $50,11 \%$ sedangkan kedalam 6-7 m yaitu $43,42 \%$. Karang mati beralga merupakan karang yang sudah mati dan permukaannya telah ditumbuhi oleh alga (Giyanto, 2017). Keberadaan alga akan menjadi kompetitor bagi karang sehingga karang sulit bertahan hidup, alga memiliki dampak negatif terhadap komunitas karang yang tumbuhnya lambat, sehingga jika pertumbuhannya dikendalikan maka komunitas alga akan segera mendominasi ekosistem terumbu karang (Dianastuty, 2016).

Dapat dilihat pada Gambar 4.3, persentase tutupan karang HC stasiun 2 kedalaman 3-4 m sebesar 54,75\%, sedangkan persentase tutupan karang HC pada kedalam 6-7 m sebesar 52,06\%. Menurut Keputusan Menteri Lingkungan Hidup Nomor 4 Tahun 2001 nilai HC Stasiun 2 pada kedalaman 3-4 dan 6-7 dapat dikategorikan baik.

Hasil tutupan karang Stasiun 3 dapat dilihat pada Gambar 4.4. persentase tutupan karang $\mathrm{HC}$ stasiun 3 pada kedalaman 3-4 m sebesar $27.17 \%$ sedangkan persentase tutupan pada kedalaman 6-7 m 46.93\%. Nilai HC pada stasiun 3 dapat digolongkan dalam kategori sedang, menurut Keputusan Menteri Lingkungan Hidup Nomor 4 Tahun 2001 nilai sedang dikategorikan dalam rentang 25\% 49,9\%. Pada tutupan karang stasiun 3 nilai tertinggi $\mathrm{HC}$ yaitu pada kedalaman 6-7 m.

Nilai HC pada stasiun 3 dikedalaman 3-4 $\mathrm{m}$ dan 6-7 m memiliki selisih nilai yang cukup signifikan, rendahya persentase dari tutupan $\mathrm{HC}$ dikedalaman 3-4 m ditunjang dengan persentase tutupan DCA yang tinggi yaitu $47,54 \%$ tingginya persentase DCA pada kedalaman 3-4 m banyaknya dijumpai patahan atau pecahan karang mati yang sudah ditumbuhi alga. Stasiun 3 merupakan salah satu lokasi yang ramai dikunjungi oleh wisatawan di Teluk Palembang.

Kondisi komunitas terumbu karang Teluk Palembang, Pulau Lemukutan yang dimana dapat dilihat dari jumlah nilai persentase tutupan HCnya pada setiap stasiun (HCst1+HCst2+HCst3) mendapatkan nilai persentase sebesar $44,26 \%$ 
Jurnal Laut Khatulistiwa, Vol. 4. No. 3 (October, 2020), Hal. 119-129.

Tabel 1. Kriteria tingkat persen tutupan karang

\begin{tabular}{ll}
\hline Kriteria Penilaian & PersentaseTutupan \\
\hline Rendah & $0-24,9 \%$ \\
Sedang & $25-49,9 \%$ \\
Baik & $50-74,9 \%$ \\
Baik sekali & $75-100 \%$ \\
\hline
\end{tabular}

nilai tersebut dapat digolongkan dalam kategori sedang menurut Keputusan Menteri Lingkungan Hidup nomor 4 tahun 2001, nilai sedang dikategorikan dalam rentang 25\% - 49,9\%. Pada Teluk Palembang tutupan karang tidak hidup (DC+DCA) mendominasi tutupan karang perairan Teluk Palembang yaitu sebesar $44.54 \%$. Wisata snorkeling merupakan salah satu kegiatan wisata yang rentan terhadap kerusakan terumbu karang (Webler and Jakubowski, 2016)

Berdasarkan pengamatan dilapangan Teluk Palembang merupakan lokasi jalur singgah kapal nelayan maupun wisatawan yang merupakan juga penyebab patahnya atau matinya terumbu karang diakibatkan oleh penurunan jangkar kapal yang langsung mengenai terumbu karang itu sendiri. Tingginya tingkat aktivitas dan interaksi manusia dengan lingkungan, berpotensi menurunkan daya dukung lingkungan khususnya ekosistem terumbu karang. Seperti yang diungkapkan oleh World Research Institute (2000) dan Ranjbar (2010), Wisata snorkeling merupakan salah satu kegiatan wisata yang rentan terhadap kerusakan terumbu karang (Webler and Jakubowski, 2016).

Tingginya nilai persentase tutupan DCA (Dead Coral With Algae) di Teluk Palembang sangat mempengaruhi rendahnya tutupan persentase HC dimana, Alga merupakan salah satu k ompetitor hidup bagi terumbu karang (Prasetia, 2015). Tingginya persentase tutupan DCA disebabkan produktivitas primer yang tinggi, untuk tutupan DCA bisa dilihat pada Gambar 4.5

\subsubsection{Lifeform Terumbu Karang}

Lifeform atau bentuk pertumbuhan terumbu karang pada stasiun 1 kedalaman 3-4 $\mathrm{m}$ bentuk pertumbuhan yang mendominasi yaitu bentuk CM (Coral Massive) yang mempunyai persentase mencapai $21.988 \%$, sama halnya pada kedalaman 6-7 m bentuk pertumbuhan yang mendominasi yaitu bentuk CM (Coral Massive) sebesar 40.356\%.

Lifeform terumbu karang stasiun 2 dapat dilihat pada gambar 4.6, lifeform atau bentuk pertumbuhan karang pada stasiun 2 kedalaman 3-4 m bentuk pertumbuhan yang mendominasi yaitu bentuk ACT (Acropora Tabulate) yang mempunyai persentase sebesar $16.827 \%$ dan diikuti oleh bentuk CM (Coral Massive) 12.029\% yang memiki selisih tidak terlalu jauh dengan bentuk ACT, sedangkan pada kedalaman 6-7 $\mathrm{m}$ bentuk pertumbuhan yang mendominasi yaitu bentuk CM (Coral Massive) 26.99\%.

Bentuk pertumbuhan karang pada stasiun 3 kedalaman 3-4 m bentuk pertumbuhan yang mendominasi yaitu bentuk CM (Coral Massive) yang mempunyai persentase sebesar $12.219 \%$, sama halnya pada kedalaman 6-7 m bentuk pertumbuhan terumbu karang yang mendominasi yaitu bentuk CM (Coral Massive) sebesar $18.66 \%$.

Lifeform atau bentuk pertumbuhan terumbu karang pada Teluk Palembang yang mendominasi adalah bentuk CM (Coral Massive), nilai persentase dari bentuk petumbuhan CM (Coral Massive) mencapai 22,043\%, CM (Coral Massive) merupakan bentuk pertumbuhan yang paling sering dijumpai pada teluk Palembang, Bentuk CM (Coral Massive) dapat mendominasi dikarenakan bentuk fisik dari terumbu karang ini sangat kokoh. Menurut Ramadhani et al (2019) bentuk pertumbuhan CM tahan dengan arus yang kuat, hal ini didukung dengan pernyataan Luthfi et al (2018) yaitu karang dengan bentuk pertumbuhan masif memiliki ketahanan terhadap arus, gelombang, sedimentasi yang tinggi serta kenaikan suhu. 
Jurnal Laut Khatulistiwa, Vol. 4. No. 3 (October, 2020), Hal. 119-129.
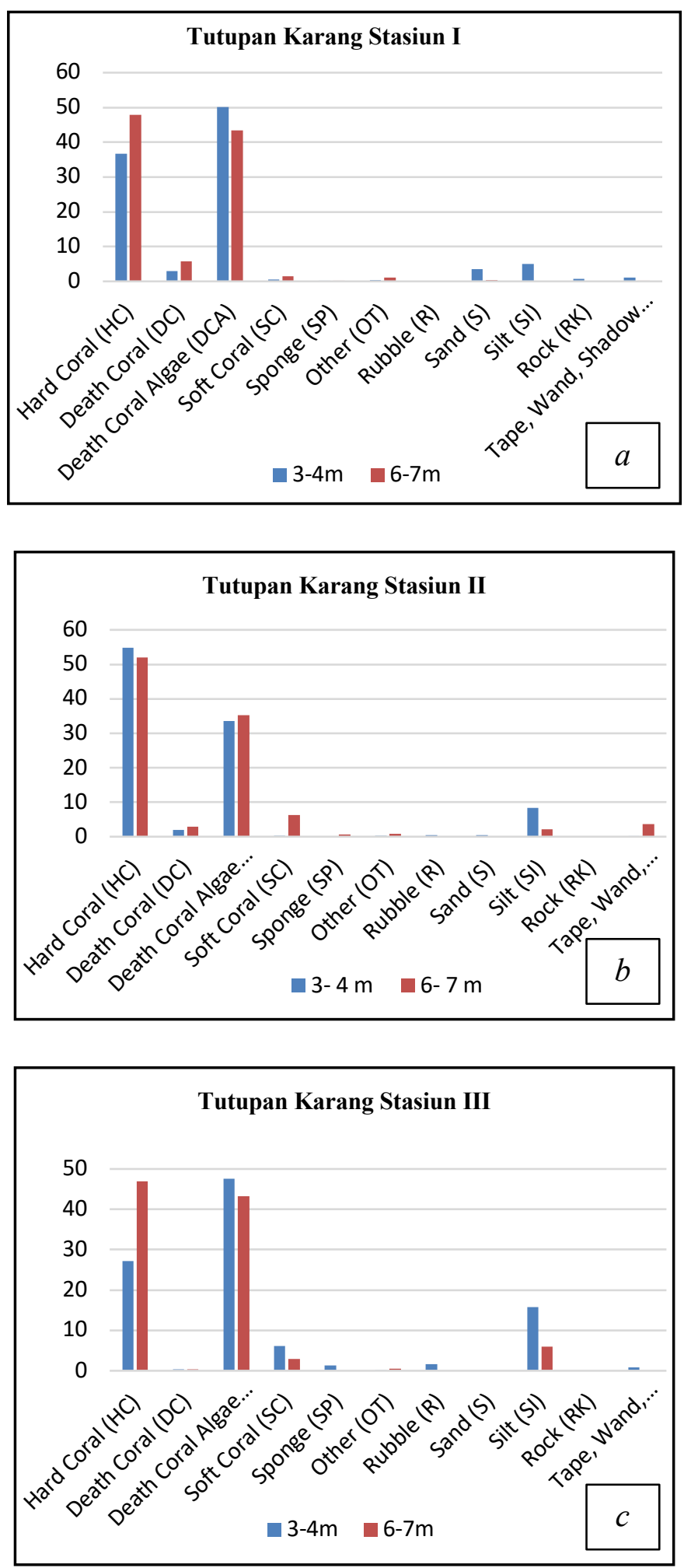

Gambar 4. Tutupan karang pada $a$ ) Stasiun $1 ; b$ ) Stasiun b; c) Stasiun 3

\subsubsection{Jenis-Jenis Terumbu Karang}

Berdasarkan hasil pengamatan terumbu karang di perairan Teluk Palembang genus yang mendominasi adalah genus Acropora sp.
(ACSP.) dimana persentase dari genus Acropora sp. (ACSP.) mencapai 31,73\%. Acropora merupakan jenis karang yang menyukai perairan dangkal yang jernih, selain itu karang Acropora merupakan genus yang 


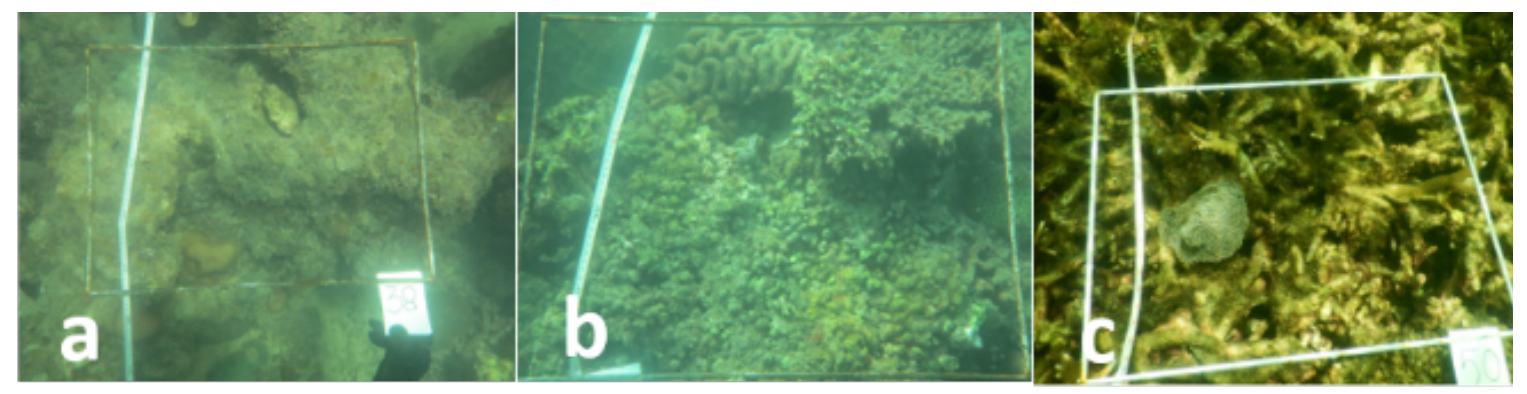

Gambar 5. Tutupan DCA pada terumbu karang

dominan diperairan Indonesia (Wahyu, 2017). Seperti dikatakan oleh Abdul et al. (2003) bahwa genus karang Acropora merupakan karang yang dominan dan habitat karang ini yaitu pada Reef slope serta perairan jernih. Bila dilihat pada perairan Teluk Palembang kecerahan perairan tergolong baik untuk pertumbuhan terumbu karang.

\subsection{Parameter Lingkungan}

Menurut Barus et al (2018) Kondisi lingkungan perairan memberikan dampak positif maupun negatif terhadap bentuk pertumbuhan terumbu karang di perairan. Adapun parameter lingkungan perairan yang diukur meliputi suhu, salinitas, DO, pH, kecerahan dan arus.

Pengukuran suhu perairan dilakukan disetiap stasiun diamana suhu pada perairan dermaga, perairan pemukiman dan perairan tanpa pemukiman memiliki nilai rentang suhu $29,86^{\circ} \mathrm{C}-$ $30,86^{\circ} \mathrm{C}$ yang dimana nilai tersebut termasuk rentang optimal kehidupan terumbu karang Berdasarkan Keputusan Menteri Lingkungan Hidup Nomor 51 Tahun 2004, suhu yang baik bagi kehidupan terumbu karang berkisar antara $28^{\circ} \mathrm{C}-32^{\circ} \mathrm{C}$. Hartoni (2011), mengatakan bahwa karang masih dapat mentolerir suhu tahunan maksimum $36^{\circ} \mathrm{C}-$ $40^{\circ} \mathrm{C}$ dan minimum $18^{\circ} \mathrm{C}$. Peningkatan suhu $2^{\circ} \mathrm{C}$ dari suhu optimal dapat mengurangi tingkat produktifitas primer karang dan Peningkatan kerusakan terumbu karang dapat disebabkan oleh peningkatan suhu (Suharsono, 2014). Berdasarkan kriteria suhu optimal diatas Nilai suhu pada stasiun pengamatan dapat dikategorikan baik bagi kehidupan terumbu karang.

Pengukuran salinitas perairan dilakukan disetiap stasiun dimana salinitas pada perairan dermaga, perairan pemukiman dan perairan tanpa pemukiman memiliki nilai rentang 30,8\% - 31,73\%o yang dimana nilai tersebut kurang dari nilai optimal dalam kehidupan terumbu karang Berdasarkan Keputusan Menteri Lingkungan Hidup Nomor 51 Tahun 2004, salinitas yang baik bagi kehidupan terumbu karang berkisar antara 33\% - 34\%o. Namun menurut Coral Watch (2011) dan Sudiarta (1995) hewan karang mempunyai toleransi salinitas berkisar antara 27-40\%. Salinitas dapat berubah akibat bertambah dan berkurangnya molekul molekul air proses penguapan air hujan dan sebaliknya jika curah hujan lebih besar dari penguapan maka salinitas berkurang dan kondisi ini tergantung dengan garis lintang dan musim (Prasetia, 2015). Berdasarkan kriteria salinitas optimal, nilai salinitas stasiun pengamatan tergolong rendah namun masih tergolong baik untuk kehidupan terumbu karang.

Pengukuran DO perairan dilakukan disetiap stasiun dimana DO pada perairan dermaga, perairan pemukiman dan perairan tanpa pemukiman memiliki nilai rentang 4 $\mathrm{mg} / \mathrm{l}$ - 5,86 mg/l yang dimana nilai tersebut masih termasuk nilai optimal dalam kehidupan terumbu karang berdasarkan Keputusan Menteri Lingkungan Hidup Nomor 51 Tahun 2004, DO yang baik bagi kehidupan terumbu karang adalah $>5 \mathrm{mg} / \mathrm{l}$. Dari penelitian yang dilakukan Patty (2018), kadar oksigen terlarut di perairan antara 4,06-6,44 mg/l masih baik untuk kehidupan terumbu karang. Berdasarkan kriteria DO optimal diatas, nilai DO pada stasiun pengamatan tergolong masih baik untuk kehidupan terumbu karang.

Pengukuran $\mathrm{pH}$ perairan dilakukan disetiap stasiun dimana $\mathrm{pH}$ pada perairan dermaga, perairan pemukiman dan perairan tanpa pemukiman memiliki nilai rentang 7,99 - 8,55 yang dimana nilai tersebut masih 
Jurnal Laut Khatulistiwa, Vol. 4. No. 3 (October, 2020), Hal. 119-129.
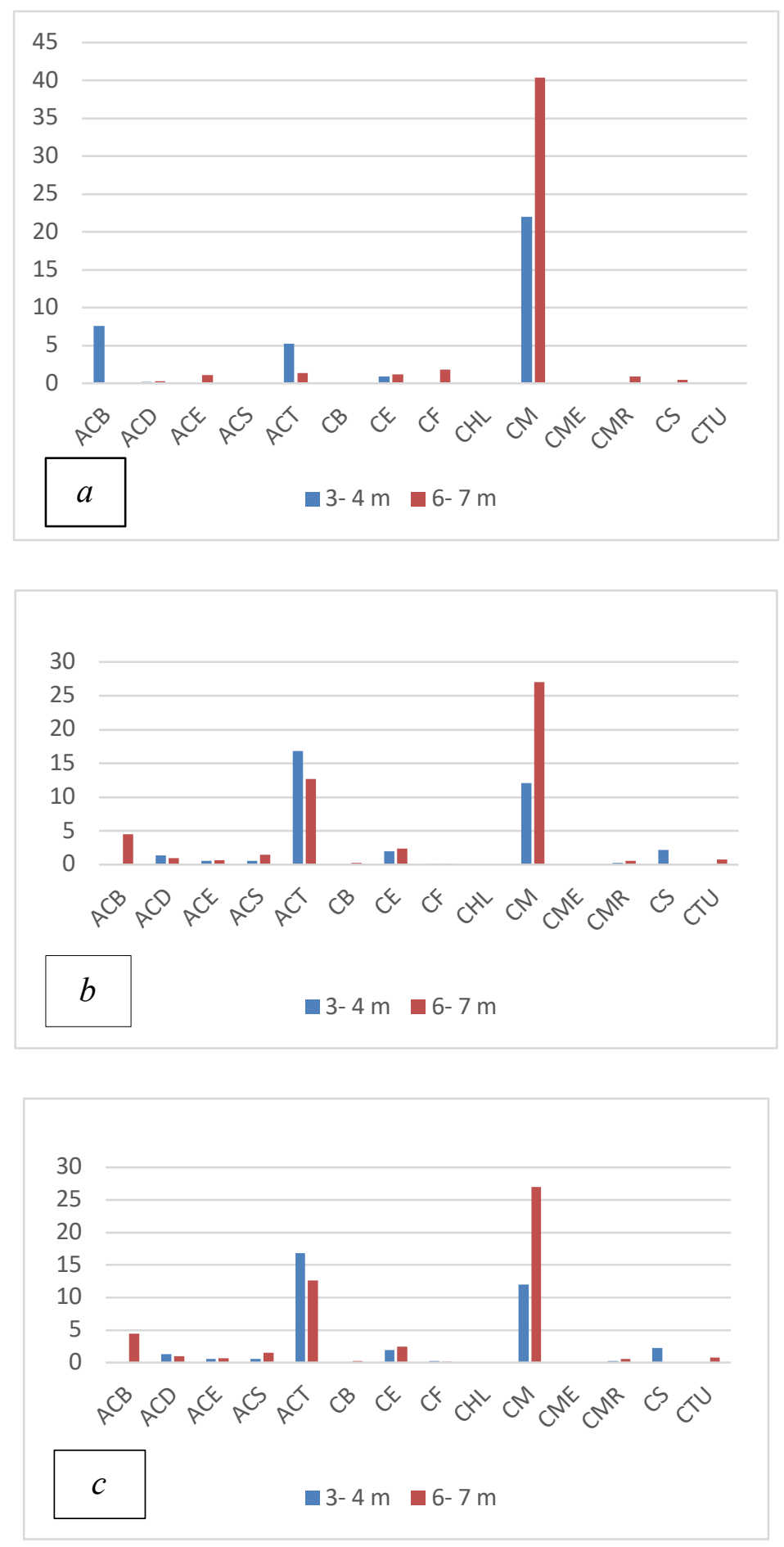

Gambar 6. Lifeform terumbu karang a) Stasiun 1; b) Stasiun 2; c) Stasiun 3

termasuk nilai optimal dalam kehidupan terumbu karang Berdasarkan Keputusan Menteri Lingkungan Hidup Nomor 51 Tahun 2004, pH yang baik bagi kehidupan terumbu karang berkisar antara $7-8,5$. Nilai $\mathrm{pH}$ dalam suatu perairan dipengaruhi oleh berbagai faktor diantaranya curah hujan dan pengaruh dari daratan maupun proses oksidasi yang dapat mengakibatkan rendahnya nilai $\mathrm{pH}$ (Edward dan Tarigan, 2003). Perubahan $\mathrm{pH}$ dapat mempunyai akibat buruk terhadap kehidupan biota laut baik secara langsung maupun tidak langsung (Prasetyo et al., 2018). Berdasarkan kriteria $\mathrm{pH}$ optimal diatas nilai 
Jurnal Laut Khatulistiwa, Vol. 4. No. 3 (October, 2020), Hal. 119-129.

Tabel 2. Nilai parameter lingkungan perairan

\begin{tabular}{|c|c|c|c|c|}
\hline \multirow[b]{2}{*}{ Parameter } & \multicolumn{3}{|c|}{ Stasiun Pengamatan } & \multirow[b]{2}{*}{$\begin{array}{c}\text { Rentang Optimal } \\
\text { (KLH No. } 51 \text { Th. 2004) }\end{array}$} \\
\hline & $\begin{array}{l}\text { Dermaga } \\
\text { (St. 1) }\end{array}$ & $\begin{array}{l}\text { Pemukiman } \\
\text { (St. 2) }\end{array}$ & $\begin{array}{c}\text { Tanpa } \\
\text { Pemukiman } \\
\text { (St. 3) }\end{array}$ & \\
\hline Suhu $\left({ }^{\circ} \mathrm{C}\right)$ & $29,86-30,65$ & $30,2-30,86$ & $30,2-30,55$ & $28-32$ \\
\hline Salinitas (\%o) & $31,5-31,73$ & $30,23-32,15$ & $30,8-31,50$ & $33-34$ \\
\hline $\mathrm{DO}(\mathrm{mg} / \mathrm{l})$ & $4-5,02$ & $4,3-5,86$ & $4,2-5,31$ & $>5$ \\
\hline $\mathrm{pH}$ & $7,99-8,55$ & $8,05-8,25$ & $7,99-8,15$ & $7-8,5$ \\
\hline Kecerahan (m) & & 4,9 & & $>5$ \\
\hline $\operatorname{Arus}(\mathrm{m} / \mathrm{s})$ & & 0,03 & & $0,05-008$ \\
\hline
\end{tabular}

pH pada stasiun pengamatan dapat dikategorikan baik bagi kehidupan terumbu karang.

Pengukuran kecerahan perairan diambil pada satu titik di bagan dimana dianggap mewakili perairan stasiun pengamatan, hasil yang didapat adalah $4,9 \mathrm{~m}$ dimana nilai tersebut sangat mendekati nilai optimal Berdasarkan Keputusan Menteri Lingkungan Hidup Nomor 51 Tahun 2004, kecerahan yang baik bagi kehidupan terumbu karang adalah $>$ $5 \mathrm{~m}$. Cahaya diperlukan dalam proses fotosintesis alga simbiotik zooxanthella untuk memenuhi kebutuhan oksigen biota terumbu karang (Akbar, 2013). Tanpa cahaya yang cukup, laju fotosintesis akan berkurang dan kemampuan karang untuk menghasilkan kalium karbonat akan berkurang pula (Harahap, 2004). Terumbu karang dalam kehidupannya memerlukan perairan yang jernih, apabila kondisi diperairan keruh akan mempengaruhi penetrasi cahaya maka laju pertumbuhan dan produksi terumbu karang akan terhambat (Guntur, 2011). Berdasarkan nilai kecerahan pada perairan stasiun pengamatan dapat dikategorikan kurang baik untuk kehidupan terumbu karang.

Pengukuran data arus diambil pada satu titik di ujung dermaga dengan pengukuran perjam selama 24 jam, didapat rata-rata arus $0,03 \mathrm{~m} / \mathrm{s}$ Pengukuran arus perairan dianggap mewakili arus perairan stasiun pengamatan, titik kordinat pengambilan sampel dapat dilihat pada Tabel 4.2. Perairan yang berarus memungkinkan karang memperoleh sumber air yang baik, memberi oksigen, mengindari pengendapan sedimen, sumber nutrien dan makanan (Sugiyanto, 2004). Faktor arus dapat berdampak baik atau buruk. Bersifat positif apabila membawa nutrien dan bahan-bahan organik yang diperlukan oleh karang dan zooxanthellae, sedangkan bersifat negatif apabila menyebabkan sedimentasi di perairan terumbu karang dan menutupi permukaan karang sehingga berakibat pada kematian karang (Prasetia, 2015). Berdasarkan nilai rata-rata kecepatan arus perairan stasiun pengamatan nilai kecepatan arus tersebut tergolong rendah karena kurang dari nilai optimal yaitu 0,05-0,08 m/s (Suharsono, 1991).

\section{Kesimpulan}

Berdasarkan hasil penelitian dapat disimpulkan bahwa Persentase tutupan karang hidup berada pada nilai $44,25 \%$, nilai tersebut menunjukan kondisi terumbu karang di Teluk Palembang Pulau Lemukutan Kalimantan Barat termasuk ke dalam kategori Sedang. Jenis (genus) yang paling dominan di Teluk Palembang Pulau Lemukutan Kalimantan Barat dari 72 genus yang ditemukan adalah genus Acropora sp. (ACSP.) dimana persentase dari genus Acropora sp. (ACSP.) mencapai 31,73\%. Berdasarkan hasil pengukuran parameter kualitas perairan di Teluk Palembang Pulau Lemukutan Kalimantan Barat termasuk kurang baik karena nilai dari salinitas, kecerahan dan arus masih belum memenuhi nilai optimal untuk pertumbuhan terumbu karang. 


\section{Ucapan Terima Kasih}

Penulis mengucapkan terimakasih kedapa Kementerian Riset, Teknologi dan Pendidikan Tinggi Republik Indonesia atas program Beasiswa Bidikmisi sehingga penulis dapat menyelesaikan riset di FMIPA UNTAN.

\section{Daftar Pustaka}

Abdul, K., K. Suryo, dan W. Indra. 2003. Panduan Pengenalan Jenis - jenis Karang Hias Yang Diperdagangkan, Assosiasi Koral dan Ikan Hias Indonesia (AKKII). Jakarta. 941p.

Akbar, M. 2013. Kaitan Kondisi Oseanografi Dengan Kepadatan Dan Keanekaragaman Karang Lunak Di Pulau Laelae, Pulau Bonebatang dan Pulau Badi. Skripsi. Makassar : Universitas Hasanuddin.

Barus, B.S., T. Prartono, dan D. Soedarma. 2018. Pengaruh Lingkungan Terhadap Bentuk Pertumbuhan Terumbu Karang Di Perairan Teluk Lampung. Jurnal Ilmu dan Teknologi Kelautan Tropis.. 10(3): 699-709

Bengen, D.G. 2009. Ekosistem dan Sumberdaya Pesisir dan Laut Serta Pengelolaan Secara Terpadu dan Berkelanjutan. Pusat Kajian Sumberdaya Pesisir dan Lautan. Bogor: Institut Pertanian Bogor.

Damanhuri, H. 2003. Terumbu Karang Kita, Pusat Kajian Mangrove dan Kawasan Pesisir. Universitas Bung Hatta Padang.

Edward dan Z. Tarigan. 2003. Pemantauan Kondisi Hidrologi Diperairan Raha P. Muna, Sulawesi Tenggara Dalam Kaitannya Dengan Kondisi Terumbu Karang. Makara. Jurnal. Sains.. 7(2): 73-82

Giyanto, M. Abrar, T.A. Hadi, A. Budiyanto, M. Hafizt, A. Salatalohy, dan M.Y. Iswari. 2017. Status Terumbu Karang Indonesia. Jakarta: Puslit Oseanografi - LIPI. 30p

Giyanto, B.H., D. Iskandar, Soedharma dan Suharsono. 2010. Effisiensi Dan Akurasi Pada Proses Analisis Foto Bawab Air Untuk Menilai Kondisi Terumbu Karang. Jurnal Oseanologi dan Limnologi di Indonesia. 36(1): 111-130

Keputusan Menteri Negara Lingkungan Hidup (KEPMEN-LH) Nomor 51. 2004. Baku Mutu Air Laut
Keputusan Menteri Negara Lingkungan Hidup, Nomor 04 Tahun 2001 Tentang Kriteria Baku Kerusakan Terumbu Karang.

Luthfi, O. M., dan T.A. Prima. 2017. Distribusi Karang Keras (scleractania) sebagai Penyusun Ekosistem Terumbu Karang di Gosong Karang Pakiman, Pulau Bawean. Jurnal Ilmu-Ilmu Perairan. 6(1):9-22.

Notoatmodjo, S. 2002. Metode Penelitian Kesehatan, Rineke Cipta. Jakarta. 207p..

Patty, S.I. dan N. Akbar. 2018. Kondisi Suhu, Salinitas, pH dan Oksigen Terlarut di Perairan Terumbu Karang Ternate, Tidore dan Sekitarnya. Jurnal Ilmu Kelautan Kepulauan. 1(2);1-10

Pranata, N. B., Muliadi, dan Aulia Seto Sandhi Sanova. 2018. Kondisi Ekosistem Terumbu Karang di Teluk Cina, Pulau Lemukutan, Kalimantan Barat. Jurnal Laut. Khat.atulistiwa. 1: 9-16

Prasetia, N.D., dan G.Y. Wisnawa. 2015. Struktur Komunitas Terumbu Karang di Pesisir Kecamatan Buleleng Singaraja. Jurnal Sains dan Teknologi. 4: 2303-3142

Prasetyo, B.T., P.S. Agustinus, Lintang, S. Yuniadi, J. Astuty, Donny, dan Prihadi. 2018. Keterkaitan Tipe Substrat dan Laju Sedimentasi dengan Kondisi Tutupan Terumbu Karang di Perairan Pulau Panggang, Taman Nasional Kepulauan Seribu. Jurnal Perikanan dan Kelautan. 9(2):1-7

Sukarno. 1993. Mengenal Ekosistem Terumbu Karang, Pustlitbang Oceanogr LIPI. 1(1):117

Wahyu, F.U., L.D. Magdalena, Priosambodo, dan M. Willem. 2017. Genera Karang Keras Di Pulau Barrang Lompo Dan Bone Batang Berdasarkan Metode Identifikasi Coral Finder. Jurnal Bioma. 2(2): 39-51

Webler, T. and K. Jakubowski. 2016. Mitigating damaging behaviors of snorkelers to coral reefs in puerto rico through a pre-trip media-based intervention. Journal Biological Conservation. 197:223-228.

Ruliyansyah, A. 2016. Evaluasi Potensi Wisata Alam Pulau Lemukutan Kabupaten Bengkayang, Kalimantan Barat. E-J. Arst. Lans. 2 (1). 
Jurnal Laut Khatulistiwa, Vol. 4. No. 3 (October, 2020), Hal. 119-129.

Dianaastuuty. 2016. Studi Kompetisi Turf Alga dan Karang Genus Acropora di Pulau Menjangan, Kepulauan Karimunjawa, Kabupaten Jepara, UNDIP, Semarang.

Ranjbar, M.S. 2010. Coral mortality and serpulid infestations with red tide, in the Persian Gulf. Journal Marine Biotecnology, Springer Verlag, UK.

Sudiarta, I.K.. 1995. Struktur Komunitas Biota Ekosistem Terumbu Karang dan Pemintakatan Kawasan Wisata Bahari Pulau Lembongan, Bali, Program Pasca Sarjana Institut Pertanian Bogor. 215p.

Harahap, K.A. 2004. Kondisi Ekosistem Terumbu Karang di Perairan Sekitar Pulau Batam, Riau, Departemen Ilmu dan Teknologi Kelautan Fakultas Perikanan dan Ilmu Kelautan Institut Pertanian Bogor.

Coral, Watch. 2011. Terumbu Karang Dan Perubahan Iklim, Panduan Pendidikan Dan Pembangunan Kesadartahuan, Australia, The University Of Queensland.

Guntur. 2011. Ekologi Karang Pada Terumbu Buatan, Ghalia Indonesia, Jakarta

Sugiyanto, G. 2004. Pertumbuhan dan Kelangsungan Hidup Karang (Caulastrea furcata) Dengan Fragmentasi Buatan di Perairan Pulau Pari Kepulauan Seribu, FPIK - IPB, Bogor

Hartoni, R. Damar, dan Y. Wardiatno. 2011. Kondisi Terumbu Karang di Perairan Pulau Tegal dan Sidodadi Kecamatan Adang Cermin Kabupaten Pasarawan Provinsi Lampung. Jurnal Maspari. 4(1): 46 - 47

Suharsono. 2014. Biodiversitas Biota Laut Indonesia. Jakarta: Puslit Oseanografi LIPI, 418p.

Suharsono. 1991. Bulu Seribu (Acanthaster planci), Balai Penelitian dan Pengembangan Biologi Laut. Jurnal Oseanologi. 16(3):17. 